\title{
Selective role of the translin/trax RNase complex in hippocampal synaptic plasticity
}

\author{
Alan Jung Park ${ }^{1,5^{*}+}$, Mahesh Shivarama Shetty ${ }^{2,3+}$, Jay M. Baraban ${ }^{4}$ and Ted Abel ${ }^{1,2,3^{*}}$ (0)
}

\begin{abstract}
Activity-dependent local protein synthesis is critical for synapse-specific, persistent plasticity. Abnormalities in local protein synthesis have been implicated in psychiatric disorders. We have recently identified the translin/trax microRNA-degrading enzyme as a novel mediator of protein synthesis at activated synapses. Additionally, translin knockout (KO) mice, which lack translin/trax, exhibit some of the behavioral abnormalities found in a mouse model of fragile $X$ syndrome (fragile $X$ mental retardation protein-FMRP-KO mice). Therefore, identifying signaling pathways interacting with translin/trax to support persistent synaptic plasticity is a translationally relevant goal. Here, as a first step to achieve this goal, we have assessed the requirement of translin/trax for multiple hippocampal synaptic plasticity paradigms that rely on distinct molecular mechanisms. We found that mice lacking translin/trax exhibited selective impairment in a form of persistent hippocampal plasticity, which requires postsynaptic protein kinase A (PKA) activity. In contrast, enduring forms of plasticity that are dependent on presynaptic PKA were unaffected. Furthermore, these mice did not display exaggerated metabotropic glutamate receptor-mediated long-term synaptic depression (mGluR-LTD), a hallmark of the FMRP KO mice. On the contrary, translin KO mice exhibited deficits in N-methyl-D-aspartate receptor (NMDAR) dependent LTD, a phenotype not observed in the FMRP knockouts. Taken together, these findings demonstrate that translin/trax mediates long-term synaptic plasticity that is dependent on postsynaptic PKA signaling and suggest that translin/trax and FMRP play distinct roles in hippocampal synaptic plasticity.
\end{abstract}

Keywords: Translin, Trax, Long-term potentiation, Long-term depression, Local protein synthesis, Hippocampal synaptic plasticity, FMRP, RNA-binding protein, microRNA, PKA

\section{Introduction}

Extensive evidence suggests that localization of key mRNAs in the vicinity of synapses and activity-mediated regulation of their translation contributes to persistent forms of synaptic plasticity related to long-term memory [1-4]. This synapse-specific, activity-dependent mechanism requires precisely regulated molecular signaling in presynaptic or postsynaptic compartments [2,

\footnotetext{
*Correspondence: alanjpark2014@gmail.com; ted-abel@uiowa.edu

${ }^{\dagger}$ Alan Jung Park and Mahesh Shivarama Shetty have contributed equally

1 Department of Biology, University of Pennsylvania, Philadelphia, PA, USA

${ }^{5}$ Present Address: Gogos Lab, Mortimer B. Zuckerman Mind Brain

Behavior Institute, Jerome L. Greene Science Center, Columbia University,

L5-053, 3227 Broadway, New York, NY 10027, USA

Full list of author information is available at the end of the article
}

3, 5]. Several RNA-binding proteins (RBPs) take part in the trafficking and translational regulation of specific mRNAs and thus allowing diversity in the mechanisms engaged by different forms of plasticity [6-8]. The RNAbinding protein translin is an evolutionarily conserved brain-enriched protein, which regulates RNA trafficking and translational control [9-12]. Together with its partner protein, translin-associated factor $\mathrm{X}$ (trax), these proteins form a microRNA-degrading enzyme that can trigger protein synthesis by reversing microRNAmediated silencing [13-15]. We have previously shown that the translin/trax RNase complex mediates activitydependent local synaptic protein synthesis required for input-specific heterosynaptic plasticity (synaptic tagging and capture) and memory formation [15]. However, the

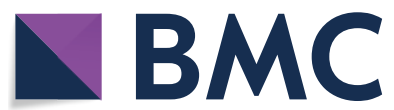

(c) The Author(s) 2020, corrected publication 2021. Open Access This article is licensed under a Creative Commons Attribution 4.0 International License, which permits use, sharing, adaptation, distribution and reproduction in any medium or format, as long as you give appropriate credit to the original author(s) and the source, provide a link to the Creative Commons licence, and indicate if changes were made. The images or other third party material in this article are included in the article's Creative Commons licence, unless indicated otherwise in a credit line to the material. If material is not included in the article's Creative Commons licence and your intended use is not permitted by statutory regulation or exceeds the permitted use, you will need to obtain permission directly from the copyright holder. To view a copy of this licence, visit http://creativecommons.org/licenses/by/4.0/. The Creative Commons Public Domain Dedication waiver (http://creativecommons.org/publicdomain/zero/1.0/) applies to the data made available in this article, unless otherwise stated in a credit line to the data. 
mechanisms that regulate translin/trax activity within synaptic compartments have not been investigated.

Our previous findings suggest that translin/trax may interact with the cAMP-PKA signaling pathway. Specifically, the microRNA targets of translin/trax are predicted to regulate the expression of PKA-anchoring proteins, cAMP-degrading phosphodiesterases (PDEs), cAMPproducing Gs-coupled $\beta 2$-adrenergic receptors and adenylyl cyclases [15]. In fact, the cAMP-PKA signaling pathway is highly localized within presynaptic or postsynaptic compartments by PKA-anchoring proteins and mediates protein synthesis required for persistent synaptic plasticity and memory formation [16-20]. Therefore, investigating whether translin/trax interacts with PKA signaling within presynaptic or postsynaptic compartments can provide clues to understanding molecular mechanisms linking translin/trax to synaptic plasticity and memory formation.

In the present study, we determined the role of translin/trax in distinct forms of synaptic plasticity, which require presynaptic or postsynaptic PKA signaling. As trax protein is unstable in the absence of translin, in the current study we used translin KO mice, which lack both translin and trax proteins $[15,21]$.

\section{Materials and methods}

All experiments were performed according to the National Institutes of Health guidelines and were fully approved by the Institutional Animal Care and Use Committee at the University of Pennsylvania and at the University of Iowa.

\section{Translin knockout (KO) mice}

The generation and maintenance of translin $\mathrm{KO}$ mice (MGI: 2677496) were described previously [21, 22]. Mice were backcrossed to C57BL/6J for more than 15 generations. Heterozygous male and heterozygous female mice were mated to produce homozygous translin $\mathrm{KO}$ mice and wildtype littermates. Mice were maintained on a $12 \mathrm{~h}$ light/12 h dark cycle with lights on at 8 am (ZT0). Food and water were available ad libitum. All experiments were performed during the light cycle using translin $\mathrm{KO}$ mice and wildtype littermates as controls. 2- to 5-month-old mice were used for all experiments except for the LTD experiments in which 4- to 6-week-old mice were used.

\section{Drugs}

Forskolin (FSK, Molecular grade, Sigma), an adenylyl cyclase activator, was freshly prepared as a $50 \mathrm{mM}$ solution in $100 \%$ ethanol and delivered at $50 \mu \mathrm{M}$ final concentration in artificial cerebrospinal fluid (aCSF) as described before [19]. (RS)-3,5-Dihydroxyphenylglycine (DHPG, Tocris), a potent agonist of group I metabotropic glutamate receptors (mGluRs), was freshly prepared as a $10 \mathrm{mM}$ solution in milliQ water and delivered at $100 \mu \mathrm{M}$ final concentration in aCSF as previously described [23].

\section{Electrophysiology}

Experiments were performed as described [15]. Briefly, both male and female 2-5-month-old mice (4-6 weeks old for LTD) were sacrificed by cervical dislocation and hippocampi were quickly collected in chilled, oxygenated aCSF $(124 \mathrm{mM} \mathrm{NaCl}, 4.4 \mathrm{mM} \mathrm{KCl}, 1.3 \mathrm{mM}$ $\mathrm{MgSO}_{4} \cdot 7 \mathrm{H}_{2} \mathrm{O}, 1 \mathrm{mM} \mathrm{NaH} \mathrm{PO}_{4} \cdot \mathrm{H}_{2} \mathrm{O}, 26.2 \mathrm{mM} \mathrm{NaHCO}$, $2.5 \mathrm{mM} \mathrm{CaCl} \cdot 2 \mathrm{H}_{2} \mathrm{O}$ and $10 \mathrm{mM}$ D-glucose) bubbled with $95 \% \mathrm{O}_{2} / 5 \% \mathrm{CO}_{2} .400 \mu \mathrm{m}$-thick transverse hippocampal slices were prepared using a manual slicer (Stoelting) and placed in an interface recording chamber at $28{ }^{\circ} \mathrm{C}$ (Fine Science Tools, Foster City, CA). The slices were constantly perfused with aCSF at $1 \mathrm{ml} / \mathrm{min}$ (or $2.5 \mathrm{ml} /$ min for the mGluR-LTD experiment). Slices were equilibrated for at least $2 \mathrm{~h}$ in aCSF. All the recordings were performed in the Schaffer collateral synapses in the CA1 stratum radiatum. The stimulus intensity was set to elicit $\sim 40 \%$ of the maximum field-EPSP amplitude determined by an input-output curve in each experiment. The first 20-min baseline values were averaged, and the average was used to normalize each initial fEPSP slope. The input-output relationship was measured as previously described [15]. To electrically induce long-term potentiation (LTP), spaced 4-train (four $1 \mathrm{~s} 100 \mathrm{~Hz}$ trains delivered 5 min apart), massed 4-train (four $1 \mathrm{~s} 100 \mathrm{~Hz}$ trains delivered $5 \mathrm{~s}$ apart), theta-burst stimulation (TBS, 15 bursts of four $100 \mathrm{~Hz}$ pulses delivered for a total of $3 \mathrm{~s}$ at $5 \mathrm{~Hz}$ ), and one-train (one $1 \mathrm{~s} 100 \mathrm{~Hz}$ train) stimulation were delivered after $20 \mathrm{~min}$ baseline recordings. To chemically induce LTP, $50 \mu \mathrm{M}$ of FSK in aCSF was bath applied to the slices for 15 min following 20-min baseline recordings. To chemically induce LTD, $100 \mu \mathrm{M}$ of DHPG in aCSF was bath applied to the slices for $10 \mathrm{~min}$ following 20-min baseline recordings. For the NMDARLTD experiments, the stimulus intensity was set to elicit $\sim 50 \%$ of the maximal fEPSP amplitude determined by an input-output curve in each experiment and LTD was induced by a prolonged low-frequency stimulation (LFS) protocol (1 Hz, $15 \mathrm{~min})[24,25]$, following 20-min baseline recordings.

\section{Western blotting}

Hippocampal tissue homogenization, protein separation and transfer to polyvinylidene difluoride (PVDF) membranes were performed as previously described [26]. Membranes were blocked in 5\% BSA or 5\% non-fat milk in TBST and incubated with primary antibodies (translin, 1:100,000; FMRP, 1:10,000, Millipore) overnight at $4{ }^{\circ} \mathrm{C}$. They were washed and incubated with appropriate 
horseradish peroxidase-conjugated goat anti-mouse or anti-rabbit IgG $(1: 10,000$, Santa Cruz) for $1 \mathrm{~h}$ in room temperature. Blots were exposed on a film by ECL and quantified using Image). The density of signal was normalized to beta-tubulin levels (1:50,000, Sigma). Translin antibody was produced (New England Peptide, Inc.) based on the sequences provided previously [27]. The antibody synthesis was based on the C-terminal sequence of the human translin (CKYDLSIRGFNKETA).

\section{Data analysis}

Data analyses were performed using Statistica 10 and GraphPad Prism 8. The maintenance of LTP or LTD was analyzed using a two-way repeated-measures ANOVA test on the last $20-\mathrm{min}$ of the recordings [15, 19]. The average of the normalized slopes over the last 20-min was compared between two groups using unpaired t-test. Western blotting data was analyzed using unpaired t-test. The ' $n$ ' used in all the experiments represents the number of mice. Differences were considered statistically significant when $p<0.05$. Data are plotted as mean \pm S.E.M.

\section{Results \\ Translin KO mice show deficits in a specific form of PKA-dependent long-lasting LTP}

In our previous study, we found that translin knockout mice display normal basal synaptic transmission measured by paired-pulse facilitation and input-output curves. These mice also exhibit unaltered transient potentiation, induced by a single $100 \mathrm{~Hz}$ stimulation, that requires neither PKA activity nor protein synthesis [15]. In the present study, we first tested long-lasting forms of LTP induced by spaced 4-train (four $100 \mathrm{~Hz}$ trains of $1 \mathrm{~s}$ each, delivered $5 \mathrm{~min}$ apart) or massed 4-train (four $100 \mathrm{~Hz}$ trains of $1 \mathrm{~s}$ each, delivered $5 \mathrm{~s}$ apart) stimulation. The latter does not depend on PKA activation, whereas the former requires postsynaptic PKA activity [28-32]. Also, the massed 4-train LTP is less sensitive to protein synthesis inhibition by anisomycin as compared to spaced 4-train LTP [31]. Hippocampal slices from translin $\mathrm{KO}$ mice showed marked impairment in spaced 4-train LTP (Fig. 1b; $\mathrm{n}=5$ for each group, two-way repeated-measures ANOVA, $\mathrm{F}_{(1,8)}=34.43$, $p=0.00038$ ). The average of the initial fEPSP slope over the last $20 \mathrm{~min}$ of the recordings was reduced in slices from translin $\mathrm{KO}$ mice compared to slices from wildtype littermates (wildtype littermates: $176.6 \pm 13.5 \%, \mathrm{n}=5$; translin KO mice: $89.5 \pm 9.6 \%, \mathrm{n}=5$, t-test, $p=0.00037$ ). On the other hand, massed 4-train LTP was unaltered in slices from translin $\mathrm{KO}$ mice as shown in Fig. $1 \mathrm{c}(\mathrm{n}=5$ for translin $\mathrm{KO}$ mice, $\mathrm{n}=5$ for wildtype littermates, two-way repeated-measures ANOVA, $\left.\mathrm{F}_{(1,8)}=0.923, p=0.365\right)$. The average of the initial fEPSP slope over the last $20 \mathrm{~min}$ of the recordings was similar between slices from translin $\mathrm{KO}$ mice and wildtype littermates (wildtype littermates: $143.6 \pm 8.2 \%, \mathrm{n}=5$; translin KO mice: $154.6 \pm 9.9 \%, \mathrm{n}=5$, t-test, $p=0.364)$.

Next, we examined two other long-lasting forms of LTP induced by either theta-burst stimulation (TBS; 15 bursts of four $100 \mathrm{~Hz}$ pulses delivered at $5 \mathrm{~Hz}$ ) or bath application of the adenylyl cyclase activator forskolin (FSK). These forms of LTP rely on increased transmitter release and require presynaptically compartmentalized PKA signaling [19, 30, 33-35]. TBS-LTP was unaffected in slices from translin $\mathrm{KO}$ mice (Fig. $2 \mathrm{a} ; \mathrm{n}=5$ for each group, two-way repeated-measures ANOVA, $\left.\mathrm{F}_{(1,8)}=0.007, p=0.94\right)$. The average of the initial fEPSP slope over the last $20 \mathrm{~min}$ of the recordings was similar between slices from translin $\mathrm{KO}$ mice and wildtype littermates (wildtype littermates: $150.03 \pm 7.8 \%, \mathrm{n}=5$; translin KO mice: $151.2 \pm 13.4 \%, \mathrm{n}=5$, t-test, $p=0.936)$. Furthermore, slices from translin $\mathrm{KO}$ mice showed no impairment in the FSK-LTP compared to the WT mice (Fig. 2b; $\mathrm{n}=5$ for translin KO mice, $\mathrm{n}=6$ for wildtype littermates, two-way repeated-measures ANOVA, $\mathrm{F}_{(1,9)}=0.07$, $p=0.79$ ). The average of the initial fEPSP slope over the last $20 \mathrm{~min}$ of the recordings was comparable between slices from translin $\mathrm{KO}$ mice and wildtype littermates (wildtype littermates: $180 \pm 14.3 \%, \mathrm{n}=6$; translin $\mathrm{KO}$ mice: $180.4 \pm 11.8 \%, \mathrm{n}=5$, t-test, $p=0.982$ ).

Taken together, these data suggest that translin is selectively involved in mediating the long-lasting form of LTP induced by spaced tetanic stimuli, but not in LTP induced by massed stimuli, TBS or forskolin.

\section{Translin KO mice exhibit unaltered mGluR-LTD} and protein levels of hippocampal FMRP, but show deficits in NMDAR-dependent LTD

One of the most well-studied RBPs is fragile X mental retardation protein (FMRP). Exaggerated metabotropic glutamate receptor-mediated LTD (mGluR-LTD) is a well characterized phenotype of FMRP KO mice and has been proposed as an underlying mechanism of fragile X syndrome [36-38]. Because both translin/trax and FMRP mediate local protein synthesis [15, 38], we tested mGluR-LTD in hippocampal slices from translin $\mathrm{KO}$ mice. In contrast to the findings from FMRP KO mice, mGluR-LTD was unaffected in slices from translin $\mathrm{KO}$ mice (Fig. 3a; $\mathrm{n}=5$ for each group, two-way repeated measures ANOVA, $\left.\mathrm{F}_{(1,8)}=0.08, p=0.79\right)$. The average of the initial fEPSP slope over the last $20 \mathrm{~min}$ of the recordings was comparable between slices from translin $\mathrm{KO}$ mice and wildtype littermates (wildtype littermates: $75.9 \pm 3.2 \%, \mathrm{n}=5$; translin $\mathrm{KO}$ mice: $78.9 \pm 3.1 \%, \mathrm{n}=5$, t-test, $p=0.473)$. We reasoned that if translin and FMRP are functionally independent, loss of 
a

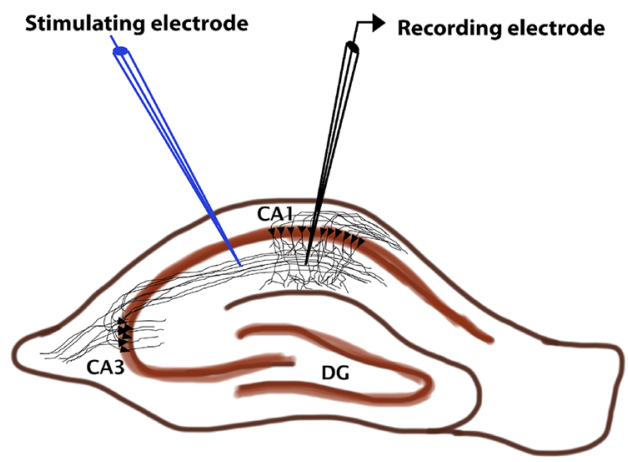

C
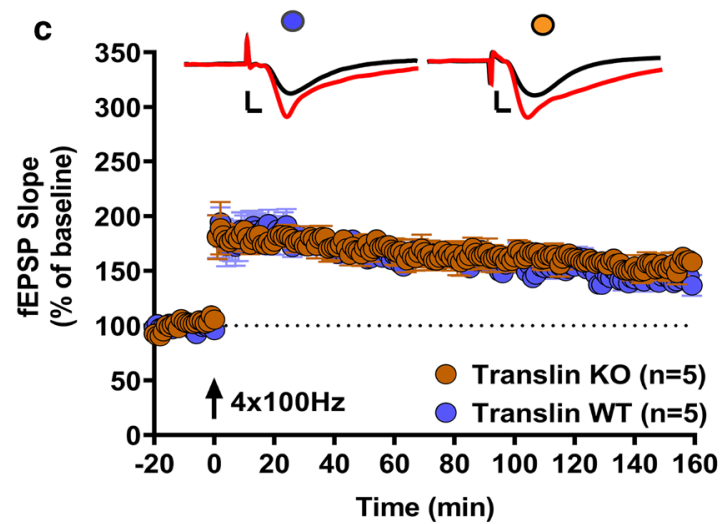

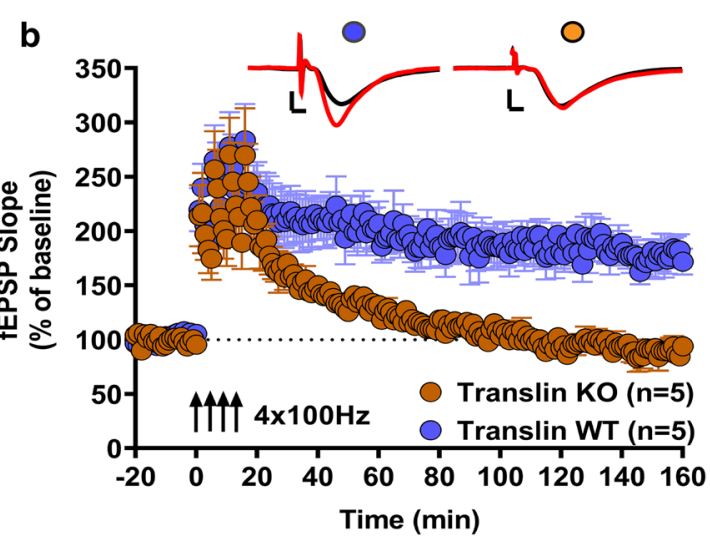

Fig. 1 Translin KO mice exhibit deficits in a postsynaptic PKA-dependent form of long-lasting LTP. a A schematic representation of a hippocampal slice showing the placement of electrodes for field-EPSP recordings in the CA1 stratum radiatum upon stimulation of Schaffer collaterals. $\mathbf{b}$ Hippocampal slices from translin KO mice ( $n=5 ; 3$ males, 2 females) showed impaired long-lasting LTP induced by spaced 4-train stimulation (four $1 \mathrm{~s} 100 \mathrm{~Hz}$ stimuli delivered 5 min apart) compared to slices from wildtype littermates ( $n=5 ; 1$ male, 4 females) (two-way repeated-measures ANOVA, $F_{(1.8)}=34.43, p=0.00038$ ). $c$ Massed 4-train stimulation (four $1 \mathrm{~s} 100 \mathrm{~Hz}$ trains delivered $5 \mathrm{~s}$ apart) elicited long-lasting LTP that was not significantly different between slices from translin $\mathrm{KO}$ mice $(n=5 ; 2$ males, 3 females) and wildtype littermates $(n=5 ; 1$ male, 4 females) (two-way repeated-measures ANOVA, $F_{(1,8)}=0.923, p=0.365$ ). Representative traces before (black) and after (red) stimulation are shown on top of each graph. Scale bars for traces $2 \mathrm{mV}, 2 \mathrm{~ms}$.' $n$ ' refers to the number of mice used. Error bars reflect S.E.M

translin/trax should not cause a compensatory increase in FMRP protein levels. Indeed, Western blot analyses showed no changes in the protein levels of hippocampal FMRP in translin $\mathrm{KO}$ mice relative to wildtype littermates (Fig. 3b; translin KO mice: $102.5 \pm 0.4 \%, \mathrm{n}=6$; wildtype littermates: $100 \pm 4.3 \%, \mathrm{n}=6$, t-test, $p=0.36$ ).

We then investigated NMDAR-dependent LTD induced by prolonged low-frequency stimulation [24, 25], because this form of LTD is mediated by anchored PKA signaling $[39,40]$ and is not affected in the FMRP KO mice [37]. We found that NMDAR-LTD induced by prolonged LFS was impaired in slices from the translin KO mice $(\mathrm{n}=7)$ compared to the wildtype littermates $(\mathrm{n}=5)$ (Fig. 3c; two-way repeated measures ANOVA, $\left.\mathrm{F}_{(1,10)}=5.342, p=0.043\right)$. The average of the fEPSP slopes over the last 20-min recordings was significantly different between slices from translin $\mathrm{KO}$ mice and wildtype littermates (translin $\mathrm{KO}$ mice: $94.9 \pm 0.3 \%$, $\mathrm{n}=7$; wildtype littermates: $71.2 \pm 0.3 \%, \mathrm{n}=5 ; \mathrm{t}$-test, $p=0.043)$.

Together, these data indicate that translin/trax and FMRP play distinct roles in hippocampal synaptic plasticity.

\section{Discussion}

The translin/trax complex is implicated in neuropsychiatric disorders [41]. However, the role of translin/trax in synaptic plasticity is largely unknown. In a previous report [15], we provided the first evidence that translin/trax mediates activity-dependent synaptic translation that is critical for synaptic tagging and capture, a form of heterosynaptic associative plasticity [42, 43], and long-term memory. The present study further determined that translin/trax is selectively required for spaced tetani-induced LTP, a long-lasting form of hippocampal 

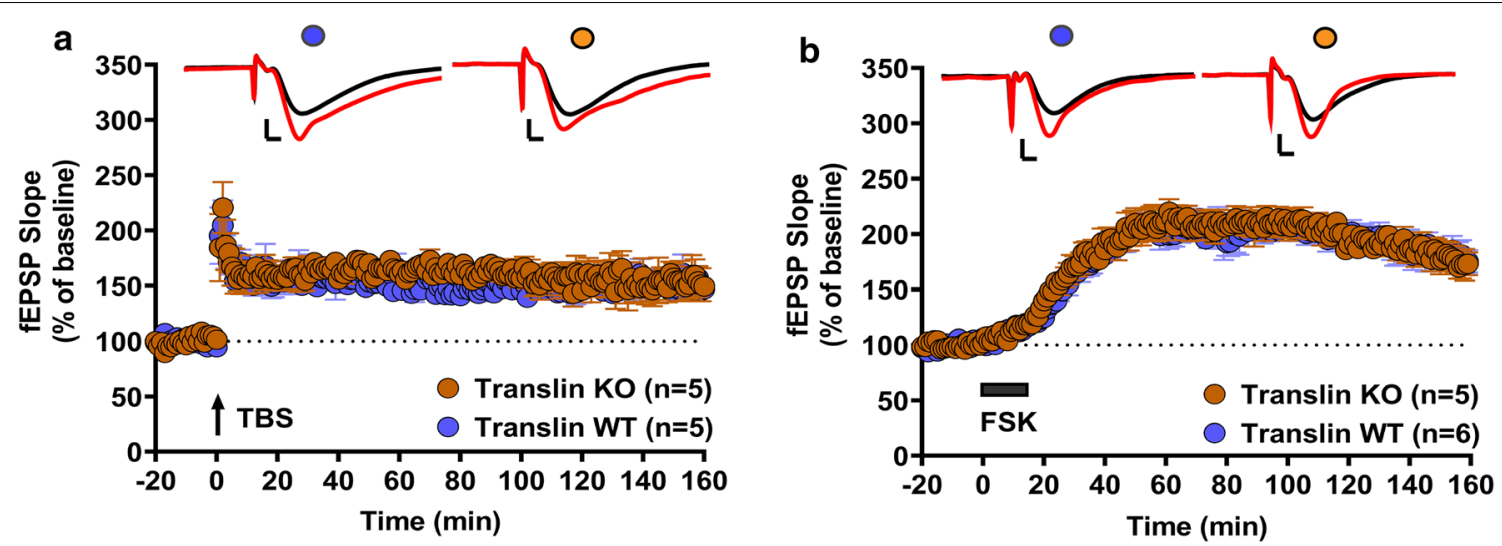

Fig. 2 Translin KO mice show no alterations in predominantly presynaptic forms of long-lasting LTP. a Theta-burst stimulation (15 bursts of four $100 \mathrm{~Hz}$ pulses delivered at $5 \mathrm{~Hz}$ for a total of $3 \mathrm{~s})$ induced similar levels of long-lasting LTP in slices from translin KO mice $(n=5 ; 1$ male, 4 females) or wildtype littermates ( $n=5 ; 2$ males, 3 females) (two-way repeated measures ANOVA, $\left.F_{(1,8)}=0.007, p=0.94\right)$. b Slices from translin $K O$ mice $(n=5$; all females) and wildtype littermates ( $n=6 ; 1$ male, 5 females) displayed similar levels of forskolin (FSK)-induced long-lasting potentiation (two-way repeated-measures ANOVA, $F_{(1,9)}=0.07, p=0.79$ ). Representative traces before (black) and after (red) stimulation are shown on top of each graph. Scale bars for traces $2 \mathrm{mV}, 2 \mathrm{~ms}$. 'n' refers to the number of mice used. Error bars reflect S.E.M

synaptic plasticity that is mediated by postsynaptic PKA activity, and also for NMDAR-mediated LTD.

We found that translin/trax is required for spaced 4-train-LTP that relies on postsynaptic PKA activity [30] but dispensable for TBS- and FSK-LTP that rely on presynaptic PKA activity [19, 30]. Further, massed 4-train LTP, which does not require PKA activation, was not affected by the loss of translin/trax. This suggests that massed 4-train LTP relies on mechanisms that do not require PKA and translin/trax for its persistence. Indeed, we have reported earlier that massed 4-train LTP is less sensitive to protein synthesis inhibition by anisomycin as compared to spaced 4-train LTP [31]. This indicates that although the persistence of massed 4-train requires protein synthesis, the mechanisms that activate protein synthesis could be different than those underlying spaced 4-train LTP. These findings highlight the role of translin/ trax in postsynaptic PKA signaling-dependent persistent synaptic plasticity. Notably, synaptic tagging and capture is impaired in the absence of translin/trax [15] but is intact when postsynaptically compartmentalized PKA signaling is disrupted [19]. However, these studies used massed 4-train-LTP, which does not rely on PKA signaling, to induce synaptic tagging and capture. Considering this experimental caveat, multi-disciplinary approaches to manipulate localized translin/trax-PKA signaling with high spatiotemporal specification will further dissect the role of translin/trax in postsynaptic PKA signaling-mediated persistent synaptic plasticity.

We found that mice lacking translin/trax display electrophysiological phenotypes that are distinct from those observed in mice lacking FMRP, regardless of sharing some common behavioral abnormalities [22]. Translin KO mice show deficits in spaced 4-train LTP (Fig. 1b) and high-frequency stimulation-induced synaptic tagging and capture [15], but FMRP KO mice do not exhibit these impairments $[38,44]$. Exaggerated mGluR-LTD is the prominent phenotype of FMRP KO mice [37], but it was not observed in translin $\mathrm{KO}$ mice (Fig. 3a). Additionally, LFS-induced NMDAR-dependent LTD showed deficits in the translin $\mathrm{KO}$ mice (Fig. 3c) whereas it is unaffected in the FMRP KO mice [37]. These strikingly contrasting synaptic plasticity phenotypes observed in FMRP KO mice and translin $\mathrm{KO}$ mice suggest distinct roles of these proteins in hippocampal synaptic plasticity. Whereas FMRP seems to predominantly play a role in certain forms of synaptic depression, translin/trax complex appears to function in specific forms of both synaptic potentiation and depression. Given the requirement of PKA signaling and protein synthesis for the persistence of both the spaced 4-train LTP [28-32] and the LFSinduced NMDAR-LTD $[39,40,45,46]$ and that they are both impaired in the translin $\mathrm{KO}$ mice strongly suggest the role of translin/trax in PKA-dependent activation of protein synthesis. Thus, our study demonstrates a selective role for translin/trax in bidirectional synaptic plasticity and provides a foundation for future studies defining signaling pathways that enable distinct synaptic stimulation to trigger the activation of this microRNA-degrading enzyme and its targets.

Based on our published and current findings, we propose a working model in which translin/trax mediates persistent synaptic plasticity (Fig. 4). During basal synaptic transmission (Fig. 4a), the translin/trax 

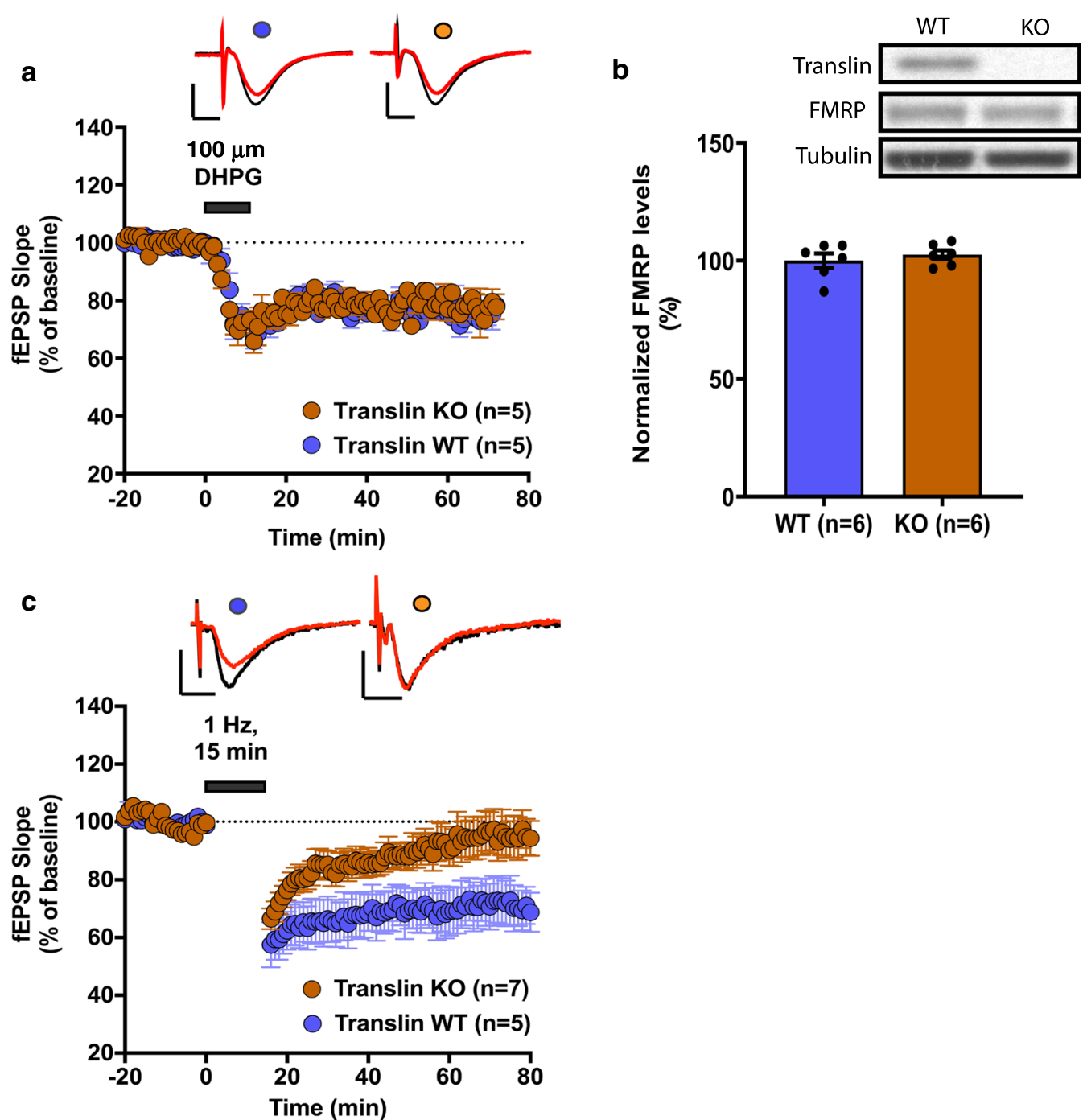

Fig. 3 Translin KO mice show unaltered mGluR-LTD and unchanged hippocampal protein levels of FMRP, but show deficits in NMDAR-dependent LTD. a Hippocampal slices from translin KO mice ( $n=5$; males) and wildtype littermates ( $n=5$; all males) displayed similar mGluR-LTD induced by bath application of $100 \mu \mathrm{M}$ of DHPG for $10 \mathrm{~min}$ (two-way repeated measures ANOVA, $\mathrm{F}_{(1,8)}=0.08, p=0.79$ ). $\mathbf{b}$ Hippocampal extracts from translin KO mice $(n=6)$ and wildtype littermates $(n=6)$ had similar protein levels of FMRP (t-test, $p=0.36)$. Beta-tubulin was used as the loading control and the expression level was normalized to the level of wildtype littermates. Representative blots are shown on top of the graph. $\boldsymbol{C}$. Hippocampal slices from translin $K O$ mice $(n=7 ; 1$ male, 6 females) showed deficits in NMDAR-dependent LTD induced by prolonged low-frequency stimulation ( $1 \mathrm{~Hz}, 15 \mathrm{~min}$ ) compared to the wildtype littermates ( $n=5 ; 3$ males, 2 females) (two-way repeated measures ANOVA, $F_{(1,10)}=5.342, p=0.043$ ). Representative traces before (black) and after (red) stimulation are shown on top of the graphs. Scale bars for traces $2 \mathrm{mV}, 5 \mathrm{~ms}$. 'n' refers to the number of mice used. Error bars reflect S.E.M

microRNA-degrading enzyme is localized within the processing bodies (P-bodies) with its RNase inactive. This is supported by our previous data showing colocalization of trax with the P-body marker GW182 in hippocampal primary neuron dendrites [15]. Given that P-bodies also contain mRNAs translationally repressed by the microRNA-induced silencing complex (miRISC) [47-49], the translin/trax complex is well-positioned to degrade microRNAs. Following persistent plasticity-inducing stimuli or learning (Fig. 4b), P-bodies are translocated to dendritic spines [50], and localized pools of PKA and the translin/trax complex are activated. Active translin/trax RNase then degrades microRNAs, relieving transcripts from translational repression. This allows the production of key plasticity-related proteins required for persistent plasticity. We have previously identified activin receptor type IC (ACVR1C) as one such plasticity-related protein [15]. Whether PKA directly activates the translin/trax 


\section{a During basal synaptic transmission}

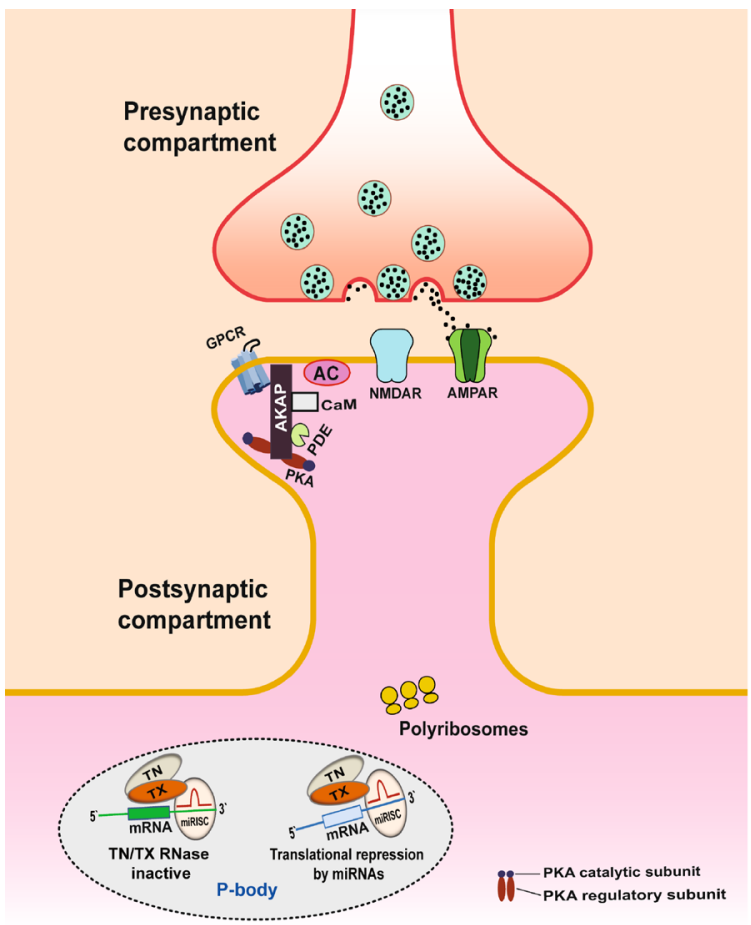

b Following stimulation that induces post-synaptic

PKA- and translation-dependent plasticity

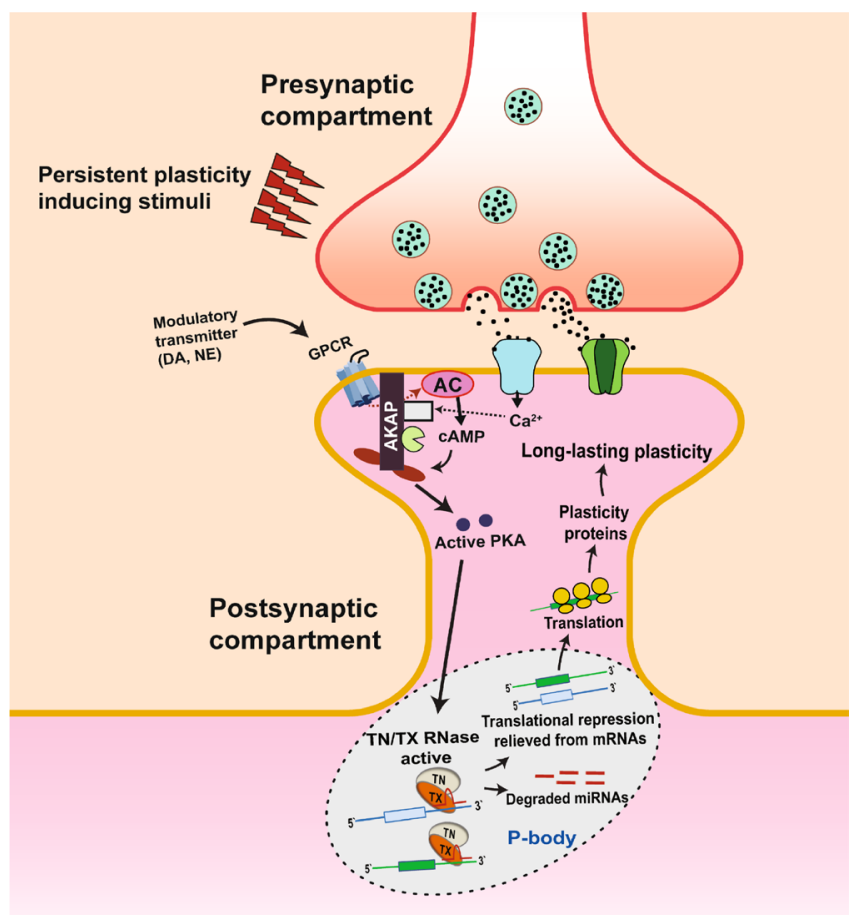

Fig. 4 A working model for the role of translin/trax RNase complex in hippocampal synaptic plasticity. a During basal synaptic transmission, the inactive translin/trax (TN/TX) RNase complex localizes to the discrete ribonucleoprotein foci called Processing body (P-body) in the postsynaptic dendrites. P-bodies also contain the microRNA-induced silencing complex (miRISC) formed by the microRNAs and other associated protein factors that bind to the mRNA transcripts and repress their translation. $\mathbf{b}$ Synaptic activity that induces persistent plasticity leads to NMDAR-mediated $\mathrm{Ca}^{2+}$ entry and GPCR activation by modulatory neurotransmitters (e.g. norepinephrine and dopamine). This results in adenylyl cyclase activation, rise in CAMP levels and PKA activation in the postsynaptic compartment. Synaptic activity also leads to dynamic changes in P-bodies causing them to localize in the vicinity of active dendritic spines. Active PKA subsequently results in activation of the translin/trax RNase in the P-bodies, either directly or through other targets. Once active, the translin/trax RNase degrades microRNAs bound to the mRNA transcripts, thus reversing the translational silencing. The released mRNAs are then translated by the polyribosomes leading to the synthesis of key plasticity-related proteins required for long-lasting synaptic plasticity

complex or acts through other targets warrants further investigation.

Taken together, these findings expand our understanding of the role of translin/trax in persistent synaptic plasticity. Future investigations are needed to directly validate the proposed model. First, the compartment-specific function of translin/trax needs to be further validated using hippocampal subregion-specific deletion of translin/trax using Cre-dependent viral strategies. Second, experiments are also needed to validate the dynamics of translin/trax localization in P-bodies following plasticity-inducing stimuli. Tagging a fluorescent reporter to translin or trax would enable tracking the localization of translin/trax but achieving this without affecting molecular interactions and RNase activity is challenging. Lastly, molecular assays to determine mechanisms by which translin/trax interacts with localized PKA signaling will be required. Given the role of translin/trax in synaptic memory mechanisms, our findings pave the way for future research aimed at elucidating the pathophysiology of neuropsychiatric disorders.

\section{Abbreviations}

aCSF: Artificial cerebrospinal fluid; AC: Adenylyl cyclase; ACVR1C: Activin receptor type 1-C; AMPAR: a-Amino-3-hydroxy-5-methyl-4-isoxazolepropionic acid receptor; CaM: Calmodulin; CAMP: Cyclic adenosine monophosphate; DHPG:

(RS)-3,5-Dihydroxyphenylglycine; fEPSP: Field excitatory postsynaptic potential; FMRP: Fragile X mental retardation protein; FSK: Forskolin; GPCR: G-protein coupled receptor; LTP: Long-term potentiation; LTD: Long-term depression; mGluR: Metabotropic glutamate receptor; miRISC: MicroRNA-induced silencing complex; NMDAR: N-methyl D-aspartate receptor; PDE: Phosphodiesterase; PKA: Protein kinase A; RBP: RNA-binding protein; RNase: Ribonuclease; TBS: Theta-burst stimulation; TN/TX:Translin/trax; Trax: Translin-associated protein-X.

\section{Acknowledgements}

Not applicable. 


\section{Authors' contributions}

AJP and TA designed the experiments. AJP performed the electrophysiology and western blotting experiments. MSS performed the NMDAR-LTD experiments. AJP and MSS performed data analysis. A.J.P and M.S.S prepared figures and wrote the manuscript with inputs from JMB and TA All the listed authors have read and approved the manuscript for publication.

\section{Funding}

The study was supported by funding from NIH RO1 MH 087463 (Abel, T.).

\section{Availability of data and materials}

All the data supporting the conclusions of this article are included within the manuscript. Original data files and any supporting materials are available upon request, from the corresponding authors.

\section{Ethics approval and consent to participate}

All the experiments presented here were performed using mice. All experiments were performed according to the National Institutes of Health guidelines and were fully approved by the Institutional Animal Care and Use Committee at the University of Pennsylvania and the University of lowa.

\section{Consent for publication}

Not applicable.

\section{Competing interests}

The authors declare that they have no competing interests.

\section{Author details}

${ }^{1}$ Department of Biology, University of Pennsylvania, Philadelphia, PA, USA. 2 Present Address: Department of Neuroscience and Pharmacology, Carver College of Medicine, University of lowa, 2-471 Bowen Science Building, 51 Newton Road, lowa City, IA 52242, USA. ${ }^{3}$ Present Address: lowa Neuroscience Institute, Carver College of Medicine, University of lowa, 2312 Pappajohn Biomedical Discovery Building, 169 Newton Road, lowa City 52242, IA, USA. ${ }^{4}$ The Solomon H. Snyder Department of Neuroscience, Johns Hopkins University School of Medicine, Baltimore, MD, USA. ${ }^{5}$ Present Address: Gogos Lab, Mortimer B. Zuckerman Mind Brain Behavior Institute, Jerome L. Greene Science Center, Columbia University, L5-053, 3227 Broadway, New York, NY 10027, USA.

Received: 16 May 2020 Accepted: 30 October 2020

Published online: 10 November 2020

\section{References}

1. Buffington SA, Huang W, Costa-Mattioli M. Translational control in synaptic plasticity and cognitive dysfunction. Annu Rev Neurosci. 2014;37(1):17-38.

2. Martin KC, Barad M, Kandel ER. Local protein synthesis and its role in synapse-specific plasticity. Curr Opin Neurobiol. 2000;10(5):587-92.

3. Sutton MA, Schuman EM. Dendritic protein synthesis, synaptic plasticity, and memory. Cell. 2006;127(1):49-58.

4. Oswald Steward JD, Shannon F. Local protein synthesis at synapses. In: Pickel MS, editor. The synapse: structure and function. London: Academic Press; 2014. p. 173-4.

5. Hafner AS, Donlin-Asp PG, Leitch B, Herzog E, Schuman EM. Local protein synthesis is a ubiquitous feature of neuronal pre- and postsynaptic compartments. Science. 2019;364:6441.

6. Fernandez-Moya SM, Bauer KE, Kiebler MA. Meet the players: local translation at the synapse. Front Mol Neurosci. 2014;7:84.

7. Thelen MP, Kye MJ. The role of RNA binding proteins for local mRNA translation: implications in neurological disorders. Front Mol Biosci. 2020;6:161.

8. Ule J, Darnell RB. RNA binding proteins and the regulation of neuronal synaptic plasticity. Curr Opin Neurobiol. 2006;16(1):102-10.

9. Claußen M, Koch R, Jin Z-Y, Suter B. Functional characterization of drosophila Translin and Trax. Genetics. 2006;174(3):1337-47.

10. Fu X, Shah A, Baraban JM. Rapid reversal of translational silencing: emerging role of microRNA degradation pathways in neuronal plasticity. Neurobiol Learn Mem. 2016;133:225-32.

11. Jaendling A. Biological roles of translin and translin-associated factor-X: RNA metabolism comes to the fore. Biochem J. 2010;429(2):225-34.
12. Li Z, Wu Y, Baraban JM. The Translin/Trax RNA binding complex: clues to function in the nervous system. Biochimica et Biophysica Acta (BBA), 2008;1779(8):479-85.

13. Asada K, Canestrari E, Fu X, Li Z, Makowski E, Wu YC, et al. Rescuing dicer defects via inhibition of an anti-dicing nuclease. Cell Rep. 2014;9(4):1471-81.

14. Baraban JM, Shah A, Fu X. Multiple pathways mediate MicroRNA degradation: focus on the Translin/Trax RNase complex. Adv Pharmacol. 2018;82:1-20.

15. Park AJ, Havekes R, Fu X, Hansen R, Tudor JC, Peixoto L, et al. Learning induces the translin/trax RNase complex to express activin receptors for persistent memory. Elife. 2017;6:e27876.

16. Costa-Mattioli M, Sossin WS, Klann E, Sonenberg N. Translational control of long-lasting synaptic plasticity and memory. Neuron. 2009;61(1):10-26.

17. Dell'Acqua ML, Smith KE, Gorski JA, Horne EA, Gibson ES, Gomez LL. Regulation of neuronal PKA signaling through AKAP targeting dynamics. Eur J Cell Biol. 2006;85(7):627-33.

18. Hernandez PJ, Abel T. The role of protein synthesis in memory consolidation: progress amid decades of debate. Neurobiol Learn Mem. 2008;89(3):293-311.

19. Park AJ, Havekes R, Choi JH, Luczak V, Nie T, Huang T, et al. A presynaptic role for PKA in synaptic tagging and memory. Neurobiol Learn Mem. 2014;114:101-12.

20. Sanderson JL, Dell'Acqua ML. AKAP signaling complexes in regulation of excitatory synaptic plasticity. Neuroscientist. 2011;17(3):321-36.

21. Chennathukuzhi V, Stein JM, Abel T, Donlon S, Yang S, Miller JP, et al. Mice deficient for testis-brain RNA-binding protein exhibit a coordinate loss of TRAX, reduced fertility, altered gene expression in the brain, and behavioral changes. Mol Cell Biol. 2003;23(18):6419-34.

22. Stein JM, Bergman W, Fang Y, Davison L, Brensinger C, Robinson MB, et al. Behavioral and neurochemical alterations in mice lacking the RNA-binding protein translin. J Neurosci. 2006;26(8):2184-96.

23. Citri A, Soler-Llavina G, Bhattacharyya S, Malenka RC. N-methyl-D-aspartate receptor- and metabotropic glutamate receptor-dependent longterm depression are differentially regulated by the ubiquitin-proteasome system. Eur J Neurosci. 2009;30(8):1443-50.

24. Dudek SM, Bear MF. Homosynaptic long-term depression in area CA1 of hippocampus and effects of $\mathrm{N}$-methyl-D-aspartate receptor blockade. Proc Natl Acad Sci USA. 1992;89(10):4363-7.

25. Mulkey RM, Malenka RC. Mechanisms underlying induction of homosynaptic long-term depression in area CA1 of the hippocampus. Neuron. 1992;9(5):967-75.

26. Vecsey CG, Peixoto L, Choi JH, Wimmer M, Jaganath D, Hernandez PJ, et al Genomic analysis of sleep deprivation reveals translational regulation in the hippocampus. Physiol Genomics. 2012;44(20):981-91.

27. Finkenstadt PM, Kang WS, Jeon M, Taira E, Tang W, Baraban JM. Somatodendritic localization of Translin, a component of the Translin/Trax RNA binding complex. J Neurochem. 2000;75(4):1754-62.

28. Duffy SN, Nguyen PV. Postsynaptic application of a peptide inhibitor of CAMP-dependent protein kinase blocks expression of long-lasting synaptic potentiation in hippocampal neurons. J Neurosci. 2003;23(4):1142-50.

29. Kim M, Huang T, Abel T, Blackwell KT. Temporal sensitivity of protein kinase a activation in late-phase long term potentiation. PLoS Comput Biol. 2010;6(2):e1000691.

30. Nie T, McDonough CB, Huang T, Nguyen PV, Abel T. Genetic disruption of protein kinase $A$ anchoring reveals a role for compartmentalized kinase signaling in theta-burst long-term potentiation and spatial memory. J Neurosci. 2007;27(38):10278-88.

31. Scharf MT, Woo NH, Lattal KM, Young JZ, Nguyen PV, Abel T. Protein synthesis is required for the enhancement of long-term potentiation and long-term memory by spaced training. J Neurophysiol. 2002;87(6):2770-7.

32. Woo NH, Duffy SN, Abel T, Nguyen PV. Temporal spacing of synaptic stimulation critically modulates the dependence of LTP on cyclic AMPdependent protein kinase. Hippocampus. 2003;13(2):293-300.

33. Bayazitov IT, Richardson RJ, Fricke RG, Zakharenko SS. Slow presynaptic and fast postsynaptic components of compound long-term potentiation. J Neurosci. 2007;27(43):11510-21.

34. Chavez-Noriega LE, Stevens CF. Increased transmitter release at excitatory synapses produced by direct activation of adenylate cyclase in rat hippocampal slices. J Neurosci. 1994;14(1):310-7. 
35. Trudeau LE, Emery DG, Haydon PG. Direct modulation of the secretory machinery underlies PKA-dependent synaptic facilitation in hippocampal neurons. Neuron. 1996;17(4):789-97.

36. Bear MF, Huber KM, Warren ST. The mGluR theory of fragile $X$ mental retardation. Trends Neurosci. 2004;27(7):370-7.

37. Huber KM, Gallagher SM, Warren ST, Bear MF. Altered synaptic plasticity in a mouse model of fragile $X$ mental retardation. Proc Natl Acad Sci USA. 2002;99(11):7746-50.

38. Sidorov MS, Auerbach BD, Bear MF. Fragile X mental retardation protein and synaptic plasticity. Mol Brain. 2013;6:15.

39. Lu Y, Zhang M, Lim IA, Hall DD, Allen M, Medvedeva Y, et al. AKAP150anchored PKA activity is important for LTD during its induction phase. J Physiol. 2008;586(17):4155-64.

40. Sanderson JL, Gorski JA, Dell'Acqua ML. NMDA receptor-dependent LTD requires transient synaptic incorporation of $\mathrm{Ca}(2)(+)$-permeable AMPARs mediated by AKAP150-anchored PKA and calcineurin. Neuron. 2016;89(5):1000-15.

41. Weng YT, Chien T, Kuan II, Chern Y. The TRAX, DISC1, and GSK3 complex in mental disorders and therapeutic interventions. J Biomed Sci. 2018;25(1):71.

42. Frey U, Morris RGM. Synaptic tagging and long-term potentiation. Nature. 1997;385(6616):533-6.

43. Redondo RL, Morris RGM. Making memories last: the synaptic tagging and capture hypothesis. Nat Rev Neurosci. 2011;12(1):17-30.
44. Connor SA, Hoeffer CA, Klann E, Nguyen PV. Fragile X mental retardation protein regulates heterosynaptic plasticity in the hippocampus. Learn Mem. 2011;18(4):207-20.

45. Kauderer BS, Kandel ER. Capture of a protein synthesis-dependent component of long-term depression. Proc Natl Acad Sci USA 2000;97(24):13342-7.

46. Manahan-Vaughan D, Kulla A, Frey JU. Requirement of translation but not transcription for the maintenance of long-term depression in the CA1 region of freely moving rats. J Neurosci. 2000;20(22):8572-6.

47. Chan SP, Slack FJ. microRNA-mediated silencing inside P-bodies. RNA Biol. 2006;3(3):97-100.

48. Luo Y, Na Z, Slavoff SA. P-bodies: composition, properties, and functions. Biochemistry. 2018;57(17):2424-31.

49. Rajgor D, Hanley JG. The ins and outs of miRNA-mediated gene silencing during neuronal synaptic plasticity. Noncoding RNA. 2016;2(1):1.

50. Oh JY, Kwon A, Jo A, Kim H, Goo YS, Lee JA, et al. Activity-dependent synaptic localization of processing bodies and their role in dendritic structural plasticity. J Cell Sci. 2013;126(Pt 9):2114-23.

\section{Publisher's Note}

Springer Nature remains neutral with regard to jurisdictional claims in published maps and institutional affiliations.
Ready to submit your research? Choose BMC and benefit from:

- fast, convenient online submission

- thorough peer review by experienced researchers in your field

- rapid publication on acceptance

- support for research data, including large and complex data types

- gold Open Access which fosters wider collaboration and increased citations

- maximum visibility for your research: over $100 \mathrm{M}$ website views per year

At $\mathrm{BMC}$, research is always in progress.

Learn more biomedcentral.com/submissions 